\title{
Holiness in spirituality
}

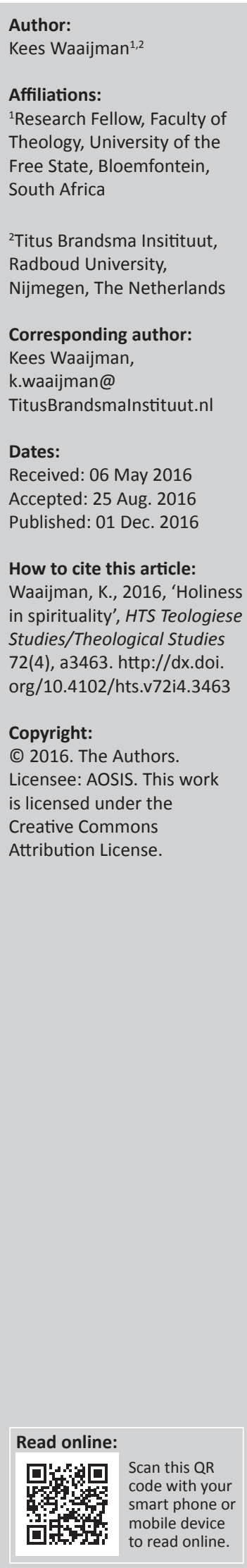

This article investigates the keyword of 'holiness'. It will analyse how holiness names and frames the field of spirituality in a specific manner. In this analysis, a phenomenological and dialogical approach will be compared and weighed, followed by a discussion of the paradigmatic method that will focus on themes from five biblical texts, namely the revelation of Jahwe's name, the holiness of Jahwe's people, the holiness of creation, the holy order of justice and peace and holiness as a mystagogical process. Some reflections will be offered in conclusion.

\section{Introduction}

Every scientific discipline uses language to define its field of interest and its approach. It chooses keywords or root metaphors to point at the core of its field of interest. The name 'psychology', for instance, indicates its field of research by the word 'psyche': psychology tries to describe and to understand the 'logic' of the human phenomenon 'psyche'. In the same way, the word 'sociology' points by its very name to the 'social' dimensions of human beings as its field of reflection: it tries to describe and to understand the 'logic' of the inter-human 'sociality'. By using keywords, both disciplines name and frame their field of study (Van Peursen 1992:54-79).

The study of spirituality also uses keywords to point to its field of interest and to indicate its approach. First of all, the word 'spirituality' itself indicates its field of interest: the 'spirit' as 'the inner dimension' of human reality, where human beings are 'open to the transcendent and ultimate dimension' (Cousins 1986:XII). The approach to the study of spirituality is to describe and understand the dynamics (the 'spirit') of this dimension (Waaijman 2007:1-113).

But 'spirituality' is not the only keyword that defines the field of spirituality. As a long established discipline, the study of spirituality is inspired by a variety of key concepts, depending on the interests and perspectives of a particular culture and religion. Such keywords function within biblical, Hellenistic, Jewish and Christian traditions. As examples, the following basic words can be mentioned: perfection, mercy, knowledge, devotion, kabbala, inner life and mysticism (Waaijman 2002:313-366).

One of the most important keywords in biblical traditions, but present in many other spiritual traditions, is 'holiness' (Kieckhefer \& Bond 1990; Sheldrake 1987). This article will investigate the keyword of 'holiness' that names and frames the field of spirituality in a specific way. This biblical concept is so important because the ethical dimension of spirituality is primary and central in it. Wyschogrod (1990:XXIII; cf. XXIV and 36ff) has pointed out in her study Saints and Postmodernism,: 'Saintly life is defined as one in which compassion for the Other, irrespective of cost to the saint, is the primary trait'. Wyschogrod is inspired by the Jewish thinker Emmanuel Levinas. For him, the Other is not defined as separated Other, isolated in a field of distance and strangeness, completely opposed to me. On the contrary, the Other has already touched me in my heart, in my selfness and has already provoked in me the responsibility which defines the core of my self. This responsibility is the source of holiness, 'an unmeasured responsibility, because it increases in the measure - or in the unmeasurableness - that a response is made' (Levinas 1996:143). This increasing responsibility as source of holiness never ends. Its inner dynamic is being 'available' - an availability that never ceases to be available, that finds no rest within itself, not even in the self-importance of servitude (Levinas 1996:144). Responsibility embodies the unconditional 'Here I am' (hinneni), and by doing so, the saint bears witness to the Infinite One, who, according to the biblical spirituality, expresses himself in the face of the Other: 'Here I am, under your eyes, at your service, your obedient servant. In the name of God' (Levinas 1996:146). As 'here I am' the saint is a trace of the Infinite One.

\section{Phenomenological versus dialogical approach}

The approach of Wyschogrod and Levinas has far reaching consequences for the perception of holiness. This can be understood fully by investigating the concept of 'holiness' as it has been developed in the area of religious studies (Eliade 1963a; Goldammer 1960; Van der Leeuw 1967), particularly in the very influential work of Rudolf Otto Das Heilige (1917). Their approach has 
changed the understanding of 'holiness' in such a way that the biblical concept has become almost invisible.

Rudolf Otto's approach of the phenomenon of holiness is strictly phenomenological: it was determined by an anthropological perspective. From this perspective, holiness appears as a human reaction of awe and fascination. Consequently, Das Heilige is defined as the mysterium fascinosum et tremendum, engendering awe, fear, wonder, shock and fascination. Holiness is conceived as a human phenomenon, appearing as a paradoxical experience: on the one hand, the holy attracts us inescapably; on the other hand; it repels and creates distance. Holiness is basically a human phenomenon, understood from human reactions to it.

The one-sidedness of this approach is indicated by some questions: is everything which provokes the paradoxical reaction of attracting and repelling, holy? Is, for instance, a pyromaniac touched by the holy because he is attracted by and repelled by fire? Is a person, fascinated by the words of a demagogue, and at same time filled with fear and awe for him, touched by a holy person? The negative answer to these questions indicated that human reaction as such does not define the phenomenon of holiness itself.

In the approach of Rudolf Otto, the same argumentation is used by some phenomenologists who understand mysticism from the perspective of extraordinary reactions. They identify mysticism with epiphenomena like ecstasy, vision, levitation and so on, rather than from the phenomenon itself which is, as was accepted in spiritual writings till the 20th century, about union with God.

A second weakness in the approach of Otto and religious studies is that holiness is understood in terms of the Totally Other (das Ganz Andere). Goldammer (1960), for instance, conceptualised holiness as something totally different, opposed to all finite or limited beings, the profane. According to Eliade (1963b), holiness is the opposite of the profane world, as the title of his book already indicates. Van der Leeuw (1967) defines holiness as the exceptional, which has to be placed within specific boundaries (temenos). In all these cases, the starting-point of conceptualisation is holiness as absolutely opposed to our world, totally other to the human realm, set apart, separated, an exceptional energy, which has to be tamed, the sacred, which should be enclosed in holy persons, holy places and holy times.

The dialogical approach to holiness is different, as can be illustrated by a brief discussion of the dialogical vision of Martin Buber, one of the founding fathers of dialogical thinking. Already 6 years after the publication of Das Heilige, Buber criticised Otto's concept. He said in his main work Ich und Du: 'Of course God is the "wholly Other"; but He is also the wholly Same (the same as I, kw), ${ }^{1}$ the wholly Present. Of course, $\mathrm{He}$ is the mysterium tremendum that appears and

1.Buber in his letter to Smith, the translator of Ich und Du: 'The wholly self ist nich was ich meine; ich meine: Gott ist nicht bloss anders als ich, sondern auch ebenso wie ich' Waaijman (1976:201). overthrows; but He is also the mystery of the self-evident, nearer to me than my I' (Buber 1958:79). For Buber holiness is not enclosed in absolute otherness, opposition, isolation. For him holiness is a dialogical concept. The Holy One is the wholly Other, but at the same time He is the wholly Same, to say it more precisely, as the Other He is the Same, because by creation He transforms us from not being into being: we are created by him, not once at some time, but every moment anew.

Buber's way of thinking is profoundly similar to Christian spirituality as is shown by Augustine's dialogical concept 'Tu autem eras interior intimo meo et superior summo meo' (You are more inward than my innermost self and higher than my highest; Augustine 397/8:3,6,11). This was also articulated by Thomas Aquinas who understood holiness as relation to God (Thomas Aquinas 1265:II-II,Q.81). His confrere Eckhart made the same observation as Augustine: 'God is nearer to my I than I am to myself. My being hangs from it, that God is near and present to me' (Meister Eckhart 1920:6). Within this tradition the Dictionnaire de la vie spirituelle defines holiness as: union with God. All creatures are essentially holy because they are united with their Creator (Molinari 1983:977-986; cf. James 1983:194-195).

In this approach to holiness, the starting point is not the human reaction of fascination and fear to a phenomenon of absolute otherness and strangeness, but the divine-human relationship. Holiness is a quality of the divine presence, including its otherness and strangeness. It is perceived as a radiating reality, asking for participation, including processes of alienation and purification (Spaemann 1988:585). It is a relational quality, not primarily a quality of human perception.

This evokes questions like: What may be this relational quality? In what way does holiness qualify presence as holy presence? Is it the divine presence as such which qualifies presence as holy presence? Or is it a specific way of being present which qualifies this presence as holy? To find answers on this kind of questions we will try to rethink the biblical notion of holiness. What does holiness mean in Scripture?

\section{The paradigmatic method}

The answers to the questions is determined by the paradigmatic method used by Emmanuel Levinas in his Talmudic Studies, which, in turn, was inspired by the tradition of Talmudic hermeneutics: 'Notions (holiness in this context KW) remain constantly in contact with the examples or refer back to them, whereas they (the notions, KW) should have been used as springboards to rise to the level of generalization' (Levinas 1994:103).

In his Talmudic Studies, the point of departure is always a concrete Talmudic text. The reader gains some spiritual insights by being initiated by Levinas in this text. These insights consistently remain connected with the reading of the text. Our hermeneutical horizon is widened by reading the text. This way the paradigmatic method returns again 
and again to the chosen paradigm, emerging from the paradigm in a longing for some insight but then returning again to the paradigm.

Five texts are selected for the paradigmatic analysis. The first one is from the book of Exodus which leads us into the core of holiness: the name of God, Jahweh. The second text is from Deuteronomy, giving some insight into the holiness of God's people. The third text is from the prophet Isaiah: a vision of the holiness of God's creation. The fourth text is from the book of Psalms, evoking the holiness of God's order of justice. The last text, again from the book of Exodus, is a mystagogical initiation in God's holiness. Together they may provide some incentives to rethink the biblical foundations of one of the most important keywords of spirituality.

\section{The revelation of the name Jahweh}

The biblical narrative which again and again has been used as basic text for the thesis of Rudolf Otto and Mircéa Eliade, is the story about Moses, leading 'his flock beyond the wilderness' seeing 'the angel of the Lord in a flame of fire out of a bush'; although the bush 'was blazing, yet it was not consumed' (Ex 3:1-3). Moses, trying to look at this great sight, was stopped by the Lord: 'Come not closer! Remove the sandals from your feet, for the place on which you are standing is holy ground' (Ex 3:5).

The attempt of Moses to 'look at' the miraculous sight expresses an attitude of mastership and ownership: the one who 'looks at' is dominating the scene. Moses is stopped from approaching and from this way of coming nearer. Eliade understands the prohibition as a support for his thesis about the inherent danger in the sacred: the ground of the mountain area is holy as such, and has, for that reason, to be set apart and protected as a sacred area (Eliade 1963b:20). The holiness of the ground is, however, not caused by the separateness and apartheid of the mountain, but by the presence and unconditional ownership of the Lord. It is not a holy place as such. And the removal of the sandals represents a renunciation of any claim to possession and an acknowledgement of God as the owner (Kornfeld \& Ringgren 1989:1187). The holy ground expresses the integrity of the owner. The removal of the sandals respects this integrity. Moses' awe and fear are not prompted by the holy ground but by the vision of the Lord (verse 6). Holiness in this narrative is relational: the unconditional ownership of the owner, on the one hand, and the unconditional reverence of the guest, on the other hand, are the two sides reciprocally determining the very essence of holiness in this narrative.

The narrative does not end with Moses' reverence for the owner of the place. The centre of the narrative is the revelation of the name 'Jahweh' by Jahweh himself. The owner of the ground reveals himself as the owner of the name. In the story on the revelation of God's name, we may discern three levels.

The first level is the proclamation of the name. On this level, the name is mentioned right from the beginning of the narrative: the angel of 'Jahweh', 'Jahweh' seeing Moses, 'Jahweh' speaking to him, and so on (verses 2, 4, 7, 15, 16, 18). The most solemn proclamation of the name 'Jahweh' at this level is made in Exodus 34:6:'Jahweh passed before Moses and proclaimed his name: Jahweh! Jahweh!'. Purely understood as proclamation, this level of revelation is outward and external. One may hear the name, without any understanding and participation.

The second level is an explanation of the name 'Jahweh', giving insight in its meaning: 'I am' (eyeh in verse 6 and twice in verse 14). This level is spelled out in this way: 'I have seen the misery of my people, I have heard their cry, I have felt their sufferings, I have come down to deliver them, I have seen their oppression, I am with you' (verses 7-12). In the verbs - I have seen, I have heard, I have felt, I have come down, I have seen, I am with you - the name is explained as being-with-you. This being-with-you is asking for an answer: God's people have to become aware of its being seen, being heard, being felt by him. On this level, the name is explicitly relational and more inward: God has clothed Godself with the being of poor people.

The third level is the most holy dimension of the name, it's innermost intimacy: 'I am: I am!' (Ex 3:14). Here, the presence of Jahweh is duplicated: 'I am: I am!' The name Jahweh appears to be the most personal and represents intimacy par excellence: 'I am: I am!' God who says to be one with the cry of the poor - 'I am with you' - says to be one with his beingwith: 'I am: I am!' His being 'the same' with the poor appears to be 'the other' in his self-presence. If holiness in itself is a modus of the divine presence - 'I am with you' - then the holiness of the name is the presence of this presence itself: 'I am: I am with you'. In this holiest presence, Jahweh reveals that being-with is about innermost intimacy: 'I am I am (with you)!' God's holy presence in the suffering of the people is not an exception or an accident, an intervention outside God's own being. On the contrary, being with God's people is the very essence of God's being-with-Godself.

This is probably the most holy place in the Bible: The purest self presence, without any ambiguity, without any corruption: unconditional, immediate and complete (Waaijman 1984). Meditating on this mystery, we not only remove the sandals from our feet but also remove the sandals of our heart, in the deepest poverty of the spirit.

\section{The holiness of God's people}

We tried to understand the keyword 'holiness' from the perspective of God's holiness: his name as his unconditional, immediate and complete presence. We have seen that this holiness, expressed in his name, exists in the freely chosen divine option: I am with the poor and this being-with is my very being. In the name 'Jahweh' God clothes Godself with the most poor and most despicable people and invites them to participate in this choice, in such a way, that they themselves become aware to be his holy people. 
This is what we read in the book of Deuteronomy, where Israel is qualified as 'holy people' (Dt 7:6; 14:2, 21; 26:19; 28:9). Again, this narrative does not say that God's people are holy as such, a holy race. These people are holy because it has received its holiness from their Lord: 'For you are a people holy to the Lord your God' (Dt 14:21). The Holy One has clothed himself by them in the moment that He has felt their sufferings. This is their holiness (Hulst 1979:307). 'Holiness is not a quality which is inherent to Israel, but a relational concept' (Hulst 1979:307). Israel participates in the holiness of the Lord, completely, immediately and unconditionally: 'For you are a people holy to the Lord your God; the Lord your God has chosen you out of all the peoples on earth to be his people, his treasured possession' (Dt 7:6; 14:2).

A group of slaves has been chosen to participate in the holiness of their Lord, or better: the Lord has chosen them, and precisely this choice is their holiness. The Lord lets them participate in his choice:

Today the Lord has obtained your agreement: to be his treasured people, as He promised you, and to keep his commandments; for him to set you high above all nations that he has made, in praise and in fame and in honour; and for you to be a people holy to the Lord your God, as he promised. (Dt 26:18-19)

Israel is a holy people because it is seen by the Lord, on the moment that they were completely invisible. They are the holiness of the Lord. Therefore, the command 'You should be holy as I am holy' (Lv 19:2) should basically be interpreted in this sense: You are holy, 'because you participate in my holiness, in the Holy One, and you are consecrated by $\mathrm{Me}^{\prime}$ (Hulst 1979:309). Jahweh has clothed himself with a despised and oppressed people: they are the clothes of the King, the Holy One. They are seen as holy people by God:

The Lord establishes you as his holy people, as he sworns to you, if you keep the commandments of the Lord your God and walk in his ways. All the peoples of the earth shall see that you are called by the name of the Lord, and they shall be afraid of you. (Dt 28:9-10)

The name of the Lord is laid upon his people. Now, the Lord is waiting for the moment that they become aware of this graceful holiness.

\section{The holiness of creation}

Jahweh did not restrict his gift of holiness to his chosen people. His whole creation is filled with Jahwe's presence. One of the most impressive narratives on this point has been told by Isaiah (Is 6; cf. Guillet 1990:186-188). This narrative has been quoted many times to support the concept of holiness as the mysterium fascinosum et tremendum, the Holy One as separated from and opposed to any earthly realm. This interpretation misses the point.

Isaiah saw the Lord sitting as king on his heavenly throne, high and lofty. Starting with this vision the story presents three perspectives: the perspective of the seraphs, the perspective of the whole earth and the perspective of the prophet.
Regarding the perspective of the seraphs: They are winged celestial beings, stationed above the throne of the Lord, protecting his holiness (Rüterswörden 1993:887-891). They belong to the heaven as the throne of the King. Although they are created as limited beings, they immediately reflect in their trisagion the holiness of the Lord: 'Holy, holy, holy!' Their song is not a commentary on his holiness; they express and embody his holy presence in the universe, including the heavenly height of creation. They are clothed by his holiness.

Regarding the whole earth: It was filled with the kabod as the impressive presence of the Lord (Is 6:1-4). Of course, the earth is earthy. But Jahweh as a King has clothed himself with this earthy reality. Now the whole earth is participating in the holiness of the Lord. Not by nature, but by participation in God's choice. Being the clothes of the King, the earth is a lightening and impressive revelation of his holiness.

Regarding the prophet: Confronted with the holiness of the Lord reflected in his creation, heaven and earth, Isaiah becomes aware of his unclean lips, his guilt and his sin. His lips were not essentially unclean. If they were impure as such, they should be removed, but now they are to be purified (Is 6:5-7). The seraph purified the unclean lips of the prophet, his guilt was removed, and his sin was blotted out. Now the prophet could hear the voice of the Lord and present himself as his servant: 'Here I am' (Is 6:8-9). As we have seen, 'Here I $\mathrm{am}^{\prime}$ is the embodiment and witness of God's holiness. The obstacles being removed, Isaiah is no longer hindered to be an instrument in the hand of the Holy One: he hears his voice and is able to say: 'Here I am' (verse 8).

Awe and fear do not appear in this narrative, not from the side of the seraphs, neither from the side of the earth, nor from the side of the prophet. Firstly, the holiness of the Lord is unfolded in its unhindered and impressive presence by the seraphs above the throne, not only in their everlasting trisagion, but in their very being. Secondly, the whole earth reflects, without any hindrance, the holiness of the Lord by receiving fully his splendid presence. His holiness is blocked by the third perspective: the impurity and sins of the prophet. After the removal of these hindrances, he is able to receive the holiness of the Lord: he hears his voice, he is able to say: 'Here I am, send $\mathrm{me}^{\prime}$, and to speak the word of the Lord (verse 8-9). In this narrative the holiness of the Lord can be understood as an impressive presence (kabod), majestically unfolding its influence in creation.

The seraphs and the earth represent the wholeness of God's creation. They are holy, because they participate in the holiness of God. No secularism can destroy this holiness. Perhaps it can destroy the sacredness of creation, but it does not touch its holiness, the integrity of creation. God's creation has been given to itself, unconditionally, completely and immediately. This holiness reveals itself in respect and reverence. 


\section{The holy order of justice and peace}

Psalm 99 repeats the phrase 'Holy is He' (verses 3, 5, 9) 3 times. The psalm, composed around the motive of holiness, can be divided into four strophes, and two stanzas. ${ }^{2}$ As in the previous texts, the psalm provides different perspectives on holiness.

In the first strophe (verses 1-3), the Lord is presented as king on Sion, sitting above the cherubs, the heavenly guardians of the Lord, above whom the Lord is enthroned (1 Chr 13:6; Ps 99:1; 80:2; 1 Sm 4:4; 2 Sm 6:2; 2 Ki 19:15; Is 37:16; cf. Freedman \& O'Connor 1984:322-334). The divine king is depicted as great, exalted and fearful. The manifestation of his royal presence is so impressive, that the people tremble and the earth shakes. It is as if the poem, by using the word 'people' (twice), will express that the Lord considers all human beings as his people (am). All nations belong already by their very being to his holiness, but they should acclaim and recognise it. This is what they should do: 'Let them acknowledge your great and awesome name. Holy is he' (verse 3).

The act centre of the first strophe is: the Lord, the divine king on Sion, enthroned on the cherubs, whose name is the Present One. This divine presence unfolds itself as great $(2 x)$, high, and awesome, in one word: holy. The second act centre is: the peoples and the earth. On the one hand, they react immediately: trembling and shaking. On the other hand, they are called to react consciously, recognising the holiness of the Lord openly and gratefully. The divine holiness is reflected immediately in trembling and shaking but asks for a conscious and public acknowledgement. No separation, no profane-sacred dichotomy, no otherness.

The second strophe ends with the same acclamation: 'Holy is $\mathrm{He}^{\prime}$. But now the divine holiness presents itself as grounding righteousness and powerful justice, done by a human king in the people of Jacob. The community is invited to exalt the Lord, who is named 'our God', and to bow deeply for him, for he, the grounder of justice, is holy.

In the first strophe Jahweh was in the centre, but his presence was just being: being the king. Now He is acting: grounding and doing justice in and through the human king and his people. This should be appreciated by the community as high and holy. Again the picture is double-woven. On the foreground, we see the justice of a king in the people of Jacob, but this justice is completely grounded and made by the Lord. And precisely this is the reason why the community should praise the Lord as holy. No awe, no fear, no separation. On the contrary, the holiness is affirmed in its acting in and through human justice as incarnation of divine justice. Holiness is performed within the deep relationship between the Lord and his people and his king in justice.

In the last two strophes, composed as one stanza, it is no longer the human king who is the point of reference. Now priests (Moses and Aaron) and the prophet (Samuel) are in 2.cf. for a poetical analysis: Fokkelman (2000:256-258). the centre. However, they actually belong to God's people, for they are 'among those who call on his name' (verse 6). Calling on the name of Jahweh is the everlasting origin of God's people, it is its very being: 'I have heard their cry...I know their sufferings' (Ex 3:7). This is the name: the cry of the oppressed people and the unconditional presence of Jahweh: 'They cried to the Lord, and He answered them' (verse 6). This is the name: the presence of God in the cry of his people. This is the most holy place: the Holy One answering his people's cry. Hence the last words of the Psalm: 'Yes, the Lord our God is holy' (verse 9).

The people of God is holy because it belongs to the inner space of the name (Ps 28,2). God has given to his people entrance to the intimacy of his name. It cries the name, and in crying his name God's people is holy. In crying the name, his people enter the holy space of God's interiority. In crying his name it receives entrance as a grace. No separation, no otherness, no exception, no taboo, but intimacy, presence. Jahweh is the cry of God's people: 'Be with us'. And his answer is: 'I am with you' (Ex 3:14).

The people of God is not only a crying people, they are also a responsive people: 'He spoke to them, they kept his decrees' (verse 7). This is the prophetic vocation of Israel: Jahweh speaks, and his people answers - answering as the immediate response of the prophet, immediately. This is the characteristic of Samuel, of Elijah, and of all the prophets: their very being is being responsive, immediately, without any hindrance, without hesitation. They do the word of Jahweh. This is the holiness of the prophet: 'Here I am'. Prophets are the incarnation of the name: 'Here I am!'

\section{Holiness as a mystagogical process}

Holiness points to the act of consecration (Kornfeld \& Ringgren 1989:1184). The famous story of the ascent of Mount Sinai by the people of God, guided by Moses provides insight in this process of consecration.

Moses and his people are instructed how 'to meet God' in his holiness (verse 17). The instruction to Moses is:

Go to the people and consecrate them today and tomorrow. Have them wash their clothes and prepare for the third day, because on the third day the Lord will come down upon Mount Sinai in the sight of all the people'. (verses 10-11)

Here, the verb 'consecrate' is used. What could be the meaning of this verb 'consecrate'? There are different interpretations of this act, because of the ambiguities of the Hebrew form of the verb, the piel-form (Kornfeld \& Ringgren 1989:1188).

Some interpret Moses' task as sanctification: placing the people into the quality and condition of holiness. But a little bit earlier, in the same narrative, it is said that the people, if they really listen to the Lord, 'shall be for Me a priestly kingdom and a holy nation', in the sense that they shall be 'My treasured possession out of all the people' (verses 5-6). 
Thus, it is not Moses who places the people in holiness, but the Lord.

Others understand the piel declaratively, meaning 'to declare the people holy'. But the context mentions no presuppositions to anticipate such an act of declaration. Moreover, the declarative authority in the narrative is the Lord as the owner of his treasured possession.

A third interpretation: Moses should command his people 'to sanctify themselves'. But this view devaluates Moses' role as mediator, because according to this interpretation the people are able to effect their own sanctification.

The interpretation I prefer is that Moses places the people of God into a condition allowing it to draw nearer to Jahweh, in order to encounter him. This is the very reason why ' $\mathrm{I}$ bore you on eagles' wings' from Egypt to Mount Sinai 'and brought you to $\mathrm{Me}^{\prime}$ (verse 4; cf. Kornfeld \& Ringgren 1989:1188).

From the viewpoint of spirituality this act of consecration is called mystagogy: facilitating people to encounter God. The narrative does not describe this facilitating process systematically. But there are enough signals to discern the main features.

The first point the mystagogue needs to consider is that the holiness of God is not a separated entity, located somewhere in the universe. On the contrary, God has already chosen his people, and by doing so his people became a holy people. As his holy people He brought them out of Egypt into the wilderness ( $3 x$ in vs. 1-2), a liminal situation, out of which $\mathrm{He}$ will bring them to himself (verse 4), because 'I am going to come to you' (verse 9). This is essential: God's people will be brought into the holy encounter with Him by himself. The initiation in the divine-human intimacy - being brought to Him - is carried out by God himself.

The divine-human encounter is intrinsically holy, for three reasons: the source of the encounter is the Holy One, his presence is sanctifying his people, and the end term is the accomplishing of Jahweh's choice, Israel to become his holy nation. Therefore, God is the main guide in this process of consecration. Although Moses is presented as the spiritual guide - 'Moses brought the people out of the camp to meet God' (verse 17) - nevertheless God himself remains the main actor in the process of consecration, for He brought his people into the desert, and He will bring his people into the intimacy with Him.

The people of God are holy. At the same time, it has to be brought into the holy encounter with God. Basically, this is a process of becoming conscious. It is a never ending process of transition. Holiness is a way. Therefore, in the narrative of the ascent of Mount Sinai the process of facilitating the sanctification of Israel by God himself is named 'preparation' (verses 11,15) for the day of encounter.
Seen from the perspective of spirituality, holiness is preparation, a transition, a way.

The aim of Moses' accompaniment is, that the people are enabled to go this way and to survive the encounter (Ex $20: 19,21)$, to understand the process as a process of being tested by God, and as a process of growth in reverence for God, to become holy people and no longer to be sinners (Ex 20,20).

The understanding of this process as 'testing' or 'proofing' is mystagogically important. Moses says: 'Do not be afraid, for God has come only to test you'. This biblical insight is a spiritual one. If the gap between an actual situation and God's destination is to be bridged, God will 'test' boundaries, in order to widen receptivity (Waaijman 2002:509-510). Holiness is experientially being tested by God, being challenged to surpass human boundaries.

The narrative of the ascent of Mount Sinai gives us a picture of Moses as a mystagogue. His mystagogical competence encompasses the following elements: facilitating the people to hear the voice of God, to understand his words, and to keep his covenant (verses 5, 8, 9); to accept its vocation, for, although 'the whole earth is mine' (verse 5), Israel is called to be 'my treasured possession, a holy nation' (verse 5); to be purified by washing their clothes (verse 10); to respect the boundaries set by God (verses 12-13) as holy limits, that is to say: to respect its integrity as God's holiness (verse 23); to understand trembling as a sign of fear and reverence (verse 16).

This mystagogal competence is named 'consecration' or 'sanctification' (verses 10,14), which is to be understood as to widen the heart of the people, gradually, in order to receive the Holy One. Human beings are inclined to resist the holiness of God. They enclose themselves in the narrowness of their concerns and their fears. They try to avoid the holy encounter with God. The mystagogical task involves breaking down the resistance of the people saying: 'Do not let God speak to us, or we will die' (Ex 20:19). Moses the mystagogue aims at the end goal of the transformation in God's holiness: hearing his voice, gazing at his face, understanding his words, keeping his covenant, and enjoying his choice.

\section{Some reflections}

The paradigmatic method is not aiming at a system. The five examples are springboards inviting us to jump, again and again. Insights jumping up in our mind may help us to find our way in the field of spirituality. But our reflections remain constantly in contact with the examples. For me, four insights jumped up in me.

A first insight: the notion of 'holiness' in Scripture can be understood as 'what belongs to God, unconditionally, immediately, and totally'. Unconditionally, because what belongs to God is not submitted to any condition, beforehand or afterwards. Immediately, because what belongs to God is 
not mediated by anyone or anything. Totally, because nothing is excluded from this belonging to God.

Secondly, God has chosen his creation, his people and his order of justice to belong to Him. By his choice they are holy. Being holy, they are called to participate consciously and publicly in his holy choice.

My third point of reflection: human holiness is a process, a process of becoming aware. The face of Moses, being in touch with God's intimacy, is burning. He was not aware of this transforming power of God's holy face. To come nearer to God's holy intimacy, people should be brought to it by God himself. Therefore, mystagogy is needed to come near to God's holiness.

My last point of reflection: holiness is not only awareness, it is above all holy practice. God has chosen his creation, his people, his order of justice. This is their holiness. But now they have to do God's holy choice by doing holiness in their daily life. The grace of holiness is asking for unconditional respect: 'You should be holy as I am holy' (Lv 19:2). From the viewpoint of holiness, spirituality is essentially ethical.

\section{Acknowledgements Competing interests}

The authors declare that they have no financial or personal relationships which may have inappropriately influenced them in writing this article.

\section{References}

Augustine, 397/8, 'Confessiones', in J.-P. Migne (ed.), Sancti Aurelii Augustini, Hipponensis Episcopi, opera omnia ... Tomus primus, pp. 659-868, Garnier, Paris (this edition 1841).

Buber, M., 1958, I and Thou, transl. R. Smith, Scribner, New York.

Cousins, E. (ed.), 1986, World spirituality. An encyclopedic history of the religious quest, Crossroad, New York.
Eliade, M., 1963a, Patterns in comparative religion, Meridian, Cleveland, $\mathrm{OH}$. Eliade, M., 1963b, The sacred and the profane, Harcourt, Brace \& World, New York. Fokkelman, J., 2000, Major poems of the Hebrew Bible, vol. 2, Van Gorcum, Assen.

Freedman, D. \& O'Connor, P., 1984, 'cheroub', in H.-J. Fabry \& H. Ringgren (eds.), Theologisches Wörterbuch zum Alten Testament, vol.4, pp. 322-334, Kohlhammer, Stuttgart.

Goldammer, K., 1960, Die Formenwelt des Religiösen, Kröner, Stuttgart.

Guillet, J., 1990, 'Sainteté de Dieu', in Dictionnaire de Spiritualité, vol. 14, pp. 186-188, Beauchesne, Paris.

Hulst, A., 1979, 'am/goj', in E. Jenni \& C. Westermann (eds.), Theologisches Handwörterbuch zum Alten Testament, vol. 2, pp. 290-325, Chr. Kaiser Verlag, München.

James, E., 1983, 'Holiness', in G. Wakefield (ed.), A dictionary of Christian spirituality, pp. 194-195, SCM Press, London.

Kieckhefer, R. \& Bond, G. (eds.), 1990, Sainthood. Its manifestations in world religions, University of California Press, Berkeley, CA.

Kornfeld, W. \& Ringgren, H., 1989, 'qdš', in H.-J. Fabry \& H. Ringgren (eds.), Theologisches Wörterbuch zum Alten Testament, vol. 6, pp. 1179-1204, Kohlhammer, Stuttgart.

Levinas, E., 1994, Beyond the verse, transl. G. Mole, The Athlone Press, London.

Levinas, E., 1996, 'God and philosophy', in A. Peperzak, S. Critchley \& R. Bernasconi (eds.), Emmanuel Levinas. Basic Philosophical Writings, pp. 129-148, Indiana University Press, Bloomington, IN.

Meister Eckhart, 1920, Meister Eckharts Mystische Schriften, transl. G. Landauer, Karl Schnabel Verlag, Berlin.

Molinari, P., 1983, 'Saint', in S. de Fiores et al. (ed.),Dictionnaire de la vie spirituelle, pp. 977-986, Cerf, Paris.

Otto, R., 1917, Das Heilige, Trewendt u. Granier, Breslau.

Rüterswörden, U., 1993, 'śaraph', in H.-J. Fabry \& H. Ringgren (eds.), Theologisches Wörterbuch zum Alten Testament, vol.7, pp. 887-891, Kohlhammer, Stuttgart.

Sheldrake, P., 1987, Images of holiness. Explorations in contemporary spirituality, Darton, Longman, \& Todd, London.

Spaemann, H., 1988, 'Heilig/Heiligkeit', in C. Schütz (ed.), Praktisches Lexikon der Spiritualität, pp. 585-594, Herder, Freiburg.

Thomas Aquinas, 1265, Sancti Thomae de Aquino Summa theologiae, Editiones Paulinae, Alba (this edition 1962).

Van der Leeuw, G., 1967, Religion in essence and manifestation, Peter Smith Glouchester, MA.

Van Peursen, C., 1992, Verhaal en werkelijkheid. Een deiktische ontologie, Kok Agora, Kampen.

Waaijman, K., 1976, De mystiek van ik en jij, Bijleveld, Utrecht.

Waaijman, K., 1984, Betekenis van de naam Jahwe, Kok, Kampen.

Waaijman, K., 2002, Spirituality. Forms, foundations, methods, Peeters, Leuven.

Waaijman, K., 2007, 'Spirituality - A multifaceted phenomenon. Interdisciplinary explorations', Studies in Spirituality 17, 1-113. http://dx.doi.org/10.2143/SIS.17.0. 2024643

Wyschogrod, E., 1990, Saints and postmodernism. Revisiting moral philosophy, The University of Chicago Press, Chicago, IL. 